\title{
IQ Domain-Containing Protein J
}

National Cancer Institute

\section{Source}

National Cancer Institute. IQ Domain-Containing Protein!. NCI Thesaurus. Code C98107.

IQ domain-containing protein J (159 aa, $18 \mathrm{kDa}$ ) is encoded by the human IQC) gene.

This protein may be involved in calmodulin binding. 